\title{
ANALISIS KEMAMPUAN BERPIKIR KRITIS PESERTA DIDIK DALAM PEMECAHAN MASALAH FLUIDA DINAMIS DENGAN MODEL PEMBELAJARAN STUDENT ORIENTED
}

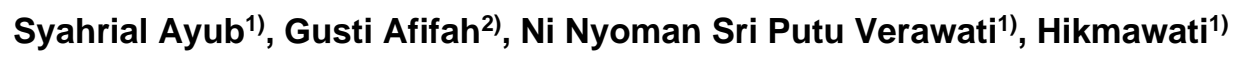 \\ 1)Program Studi Pendidikan Fisika, FKIP, Universitas Mataram, Mataram, NTB, Indonesia \\ ${ }^{2}$ SMA Negeri 2 Mataram, Dinas Pendidikan Kota Mataram, Mataram, NTB, Indonesia \\ Corresponding author: Syahrial Ayub \\ E-mail : syahrial_ayub@unram.ac.id
}

Diterima 25 April 2021, Direvisi 05 Mei 2021, Disetujui 06 Mei 2021

\begin{abstract}
ABSTRAK
Mengajar berpikir kritis kepada peserta didik di sekolah menengah telah menjadi perhatian dalam beberapa dekade terakhir. Pembelajaran menggunakan model student oriented diharapkan mampu menggerakkan peserta didik berpikir kritis dan selanjutnya melakukan investigasi dalam pembelajaran. Penelitian ini bertujuan menganalisis kemampuan berpikir kritis peserta didik dalam pemecahan masalah fluida dinamis dengan model pembelajaran student oriented. Tujuan ini akan dicapai dengan melakukan penelitian eksperimen dengan desain one group pretest-postest. Penelitian melibatkan 17 peserta didik kelas XI MIPA 8 di SMA Negeri 2 Mataram yang menjadi sampel penelitian. Kemampuan berpikir kritis diukur menggunakan 10 instrumen tes yang berbentuk essay. Instrumen tes yang digunakan telah teruji validitas dan reliabilitasnnya. Data kemampuan berpikir kritis dianalisis secara deskriptif dan statistik. Hasilnya menunjukkan bahwa penerapan model pembelajaran student oriented pada pemecahan masalah fluida dinamis pada peserta didik mampu meningkatkan kemampuan berpikir kritis dan hasil belajarnya.
\end{abstract}

Kata kunci : kemampuan berpikir kritis; model pembelajaran student oriented

\begin{abstract}
Teaching critical thinking to secondary school has been a concern in the last few decades. Learning using the student-oriented model is expected to be able to move students to think critically and then carry out investigations in learning. The experimental research with one group pretest-posttest design. This research involving 17 students of class XI MIPA 8 at SMA Negeri 2 Mataram as a research sample. Critical thinking ability were measured using 10 essay test items. The test instrument used has been tested for validity and reliability. The data of critical thinking ability were analyzed descriptively and statistically. The results showed that the application of the student-oriented learning model to solving dynamic fluid problems in students was able to improve their critical thinking skills and learning outcomes.
\end{abstract}

Keywords: critical thinking ability; student oriented learning model

\section{PENDAHULUAN}

Keterampilan abad ke-21 adalah (1) kreatifitas dan inovasi, (2) berpikir kritis, (3) pemecahan masalah, (4) pengambilan keputusan, (5) metakognisi. Jadi berpikir kritis merupakan keterampilan penting di abad ke-21 (Prayogi et al., 2018). Di beberapa negara maju, berpikir kritis telah menjadi kompetensi utama dalam pembelajaran di semua level pendidikan (Schmaltz et al., 2017). Di masa mendatang guru ditantang untuk berinovasi dalam melatih pemikiran peserta didik berpikir kritis (Sendag et al., 2015). Berpikir kritis merupakan pemikiran reflektif dan masuk akal yang terfokus untuk memutuskan apa yang harus dipercayai dan dilakukan (Ennis, 1989). Berpikir kritis sebagai kecenderungan pemikiran untuk terlibat langsung dalam suatu kegiatan dengan skeptimisme reflektif (McPeck, 1990). Sekolah sebagai institusi pendidikan diharapkan lebih mengutamakan proses pembelajaran yang mampu menggiring peserta didik ke arah berpikir kritis. Guru penentu keberhasilan peserta didik dalam mencapai tujuan pembelajaran diharapkan memahami konsep berpikir kritis dengan benar dan mampu menerapkannya pada pembelajaran di kelas. Namun, mengajar berpikir kritis tetap membingungkan bagi banyak guru (Bensley \& Murtagh, 2012), hal ini karena kurangnya kejelasan berbagai metode untuk pengajaran berpikir kritis (Abrami et al., 2008; Bensley \& 
Murtagh, 2012). Keterampilan berpikir kritis adalah proses kognitif peserta didik dalam menganalisis secara sistematis dan spesifik masalah yang dihadapi, membedakan masalah tersebut secara cermat dan teliti, serta mengidentifikasi dan mengkaji informasi guna merencanakan strategi pemecahan masalah. Pendapat tersebut diperkuat oleh Stobaugh (2013) yang menjelaskankan bahwa berpikir kritis adalah berpikir yang reflektif secara mendalam dalam pengambilan keputusan dan pemecahan masalah untuk menganalisis situasi, mengevaluasi argumen, dan menarik kesimpulan yang tepat. Orang yang mampu berpikir kritis adalah orang yang mampu menyimpulkan apa yang diketahuinya, mengetahui cara menggunakan informasi untuk memecahkan permasalahan, dan mampu mencari sumber-sumber informasi yang relevan sebagai pendukung pemecahan masalah. Berdasarkan penjelasan di atas, keterampilan berpikir kritis merupakan kemampuan dasar untuk memecahkan masalah. Keterampilan berpikir kritis peserta didik Indonesia masih rendah. Kemampuan peserta didik Indonesia dalam mengerjakan soal-soal dengan domain bernalar juga menunjukkan kemampuan yang masih sangat minim. Berpikir kritis sebagai kecenderungan pemikiran untuk terlibat langsung dalam suatu kegiatan dengan skeptimisme reflektif (McPeck, 1990). Bentuk pemikiran ini digunakan untuk memberikan penilaian pada informasi apa pun, kemudian menjelaskan alasannya, dan mampu menyelesaikan masalah yang tidak diketahui (Thomas, 2011), sehingga masing-masing individu dapat memahami informasi atau konten apa pun pada konteks tertentu (Zane, 2013). Berpikir kritis sering disebut berpikir independen, berpikir reflektif, atau berpikir evaluatif (Fahim \& Masouleh, 2012). Meskipun terdapat perbedaan di antara pemikiran para ahli dan peneliti sebelumnya dalam mendefinisikan pemikiran kritis, namun kesepakatan mereka nampak pada kemampuan spesifik yang tercakup sebagai indikator kemampuan berpikir kritis, yang meliputi: menganalisis suatu argumentasi, klaim-klaim, atau bukti-bukti; membuat kesimpulan menggunakan suatu penalaran baik induktif atau deduktif; menilai atau mengevaluasi; serta pengambilan keputusan (Prayogi et al., 2018). Pendidik dan orang-orang yang bergelut di dalam dunia pendidikan telah lama menyadari akan pentingnya pemikiran sebagai hasil dari pembelajaran. Model pembelajaran dengan mengintegrasikan kreativitas, inovasi dengan proses ilmiah telah dikembangkan untuk tujuan meningkatkan kemampuan berpikir kritis peserta didik.Pengembangannya merujuk pada beberapa literasi dan kajian empiris dari pengalaman, pelatihan dan penerapan di sekolah serta peneliti sebelumnya. Pengembangan ini menimbulkan kreativitas ilmiah peserta didik. Aspek aspek kreativitas ilmiah dalam bentuk penemuan masalah, pemecahan masalah, membuat hipotesis, mendesain eksperimen, dan mendesain produk (Türkmen \& Sertkahya, 2015; Ayas \& Sak, 2014; Hu et al., 2010; Aktamis \& Ergin, 2008; $\mathrm{Hu}$, \& Adey, 2010). Model pembelajaran student oriented yang dikembangkan berdasarkan struktur pembelajaran pemecahan masalah yang berorientasi pada discovery leasrning. Struktur pembelajaran memecahkan masalah adalah sebagai berikut (Klinger, 1997).

Tabel 1: Struktur Pengajaran Pemecahan

\begin{tabular}{|c|c|c|}
\hline \multicolumn{3}{|c|}{ Masalah } \\
\hline No & $\begin{array}{c}\text { Langkah } \\
\text { Pengajaran }\end{array}$ & $\begin{array}{c}\text { Tujuan Langkah } \\
\text { Pengajaran }\end{array}$ \\
\hline 1. & Motivasi & $\begin{array}{l}\text { Membangkitkan } \\
\text { rasa tertarik dan } \\
\text { keingintahuan } \\
\text { peserta didik } \\
\text { terhadap materi } \\
\text { pelajaran yang } \\
\text { akan diajarkan }\end{array}$ \\
\hline 2. & $\begin{array}{l}\text { Penjabaran } \\
\text { Masalah }\end{array}$ & $\begin{array}{l}\text { Merumuskan suatu } \\
\text { pertanyaan ilmiah }\end{array}$ \\
\hline 3. & $\begin{array}{l}\text { Penyusunan } \\
\text { Opini }\end{array}$ & $\begin{array}{l}\text { Perumusan } \\
\text { hipotesis }\end{array}$ \\
\hline 4. & $\begin{array}{l}\text { Perencanaan } \\
\text { dan Konstruksi }\end{array}$ & $\begin{array}{l}\text { Persiapan } \\
\text { peralatan } \\
\text { percobaan yang } \\
\text { akan diqunakan }\end{array}$ \\
\hline 5. & Percobaan & $\begin{array}{l}\text { Perwujudan suatu } \\
\text { reaksi alam }\end{array}$ \\
\hline 6. & Kesimpulan & $\begin{array}{l}\text { Kesimpulan suatu } \\
\text { prosedur } \\
\text { pemecahan } \\
\text { masalah }\end{array}$ \\
\hline 7. & Abstraksi & $\begin{array}{l}\text { Hasil ilmiah yang } \\
\text { sah }\end{array}$ \\
\hline 8. & $\begin{array}{l}\text { Konsolidasi } \\
\text { pengetahuan } \\
\text { melalui aplikasi } \\
\text { dan praktek }\end{array}$ & $\begin{array}{l}\text { Pengetahuan } \\
\text { komprehensif atas } \\
\text { suatu gejala alam } \\
\text { dan } \\
\text { pengintegrasian } \\
\text { hasil pendidikan }\end{array}$ \\
\hline
\end{tabular}

Struktur pembelajaran pemecahan masalah ini, di kembangkan sesuai dengan yang ditemukan pada pembelajaran di sekolah. Sekolah tempat kegiatan pembelajarannya adalah SMA Negeri 2 Mataram. Melalui kegiatan penerapan (observasi), evaluasi dan refleksi, diperoleh masukan-masukan yang berarti dalam menemukan struktur pembelajaran yang berorientasi pada peserta didik. Hasil yang 
didapatkan berupa model pembelajaran student oriented dengan struktur pembelajaran sebagai berikut:

Tabel 2: Struktur Pembelajaran Student Oriented

\begin{tabular}{|c|c|c|}
\hline $\begin{array}{l}\text { Tahap } \\
\text { Pokok }\end{array}$ & $\begin{array}{c}\text { Tahap } \\
\text { Pengajaran }\end{array}$ & $\begin{array}{c}\text { Alternatif } \\
\text { Kegiatan yang } \\
\text { dapat Dilakukan }\end{array}$ \\
\hline \multirow[t]{2}{*}{$\begin{array}{l}\text { Kegiatan } \\
\text { Awal }\end{array}$} & Pendahuluan & $\begin{array}{l}\text { - Demonstrasi } \\
\text { sesuatu yang } \\
\text { dibawa oleh } \\
\text { guru } \\
\text { - Cerita / } \\
\text { kejadian } \\
\text { - Review atau } \\
\text { melanjutkan } \\
\text { pelajaran } \\
\text { terdahulu yang } \\
\text { belum lengkap } \\
\text { - Mengamati/me } \\
\text { mbahas } \\
\text { penerapan } \\
\text { tekhnis dalam } \\
\text { lingkungan } \\
\text { - Benyanyi } \\
\text { (berhubungan } \\
\text { dengan materi } \\
\text { yang akan } \\
\text { diajarkan) } \\
\text { - Menyampaikan } \\
\text { tujuan } \\
\text { pembelajaran }\end{array}$ \\
\hline & $\begin{array}{l}\text { Pengetahuan } \\
\text { Awal Siswa }\end{array}$ & $\begin{array}{l}\text { Mengumpulkan } \\
\text { dan } \\
\text { mendiskusikan }\end{array}$ \\
\hline \multirow[t]{3}{*}{$\begin{array}{l}\text { Kegiatan } \\
\text { Inti }\end{array}$} & $\begin{array}{l}\text { Perumusan } \\
\text { pertanyaan/ } \\
\text { permasalaha } \\
\mathrm{n} \text { tentang } \\
\text { topik } \\
\text { pembelajaran }\end{array}$ & $\begin{array}{l}\text { Merumuskan } \\
\text { pertanyaan } \\
\text { atau } \\
\text { permasalahan } \\
\text { tentang topik } \\
\text { pembelajaran }\end{array}$ \\
\hline & Kegiatan & $\begin{array}{l}\text { - Melaksanakan } \\
\text { percobaan } \\
\text { - Permainan/ } \\
\text { simulasi } \\
\text { - Mengumpulkan } \\
\text { bahan/bahan } \\
\text { untuk } \\
\text { dibandingkan, } \\
\text { diklasifikasikan } \\
\text { - Periksa cara } \\
\text { kerja alat } \\
\text { teknis }\end{array}$ \\
\hline & Pengamatan & $\begin{array}{l}\text { Melakukan } \\
\text { pengamatan } \\
\text { sebanyak } \\
\text { mungkin }\end{array}$ \\
\hline
\end{tabular}

Volume 7, Nomor 1, Mei 2021. p-ISSN : 2460-9587 e-ISSN : 2614-7017

- Penjelasan oleh siswa (tebak-dugadiskusi)

- Landasan pemikiran

- Perumusan masalah

\begin{tabular}{lc}
\hline & PENJELASAN OLEH GURU \\
& (BILA DIPERLUKAN) \\
\hline Kegiatan & - Penerapan \\
Pemantapan & (sangat baik \\
& bila \\
& berhubungan \\
& dengan \\
& lingkungan \\
& siswa) \\
& - Menjawab \\
& pertanyaan \\
& - Membuat \\
& ringkasan \\
& - Pekerjaaan \\
& rumah \\
\hline
\end{tabular}

Aspek-aspek pada struktur pembelajaran student oriented diintegrasikan dengan model discovery learning sehingga mendapatkan fase pembelajaran sebagai berikut: Fase 1) motivasi, orientasi dan menemukan masalah topik pembelajaran; Fase 2) mampu memilih kegiatan yang sesuai untuk menjawab permasalahan topik pembelajaran; Fase 3) melakukan pengamatan sebanyak mungkin dari kegiatan yang dilakukan untuk menjawab permasalahan topik pembelajaran; Fase 4) mampu mendeteksi bias dan membanding kan dengan sudut pandang berbeda berdasarkan litertur, pengalaman, observasi dan penelitian; Fase 5) mampu menemukan sendiri kesimpulan pembelajaran yang dilakukan dan merupakan jawaban permasalahan topik pembelajaran dan menerapkannya dalam lingkungan sekitar (Ayub, S.2020). Penelitian ini bertujuan mengetahui pengaruh model pembelajaran student oriented terhadap kemampuan berpikir kritis peserta didik. Fasefase ini sesuai dengan indikator berpikir kritis yang diturunkan dari aktivitas kritis menurut Ennis (1989) ada 5 yaitu (1) mampu merumuskan pokok pokok permasalahan, (2) mampu mengungkapkan fakta yang dibutuhkan dalam menyelesaikan suatu masalah, (3) mampu memilih argumen logis, relevan dan akurat, (4) mampu mendeteksi bias dengan sudut pandang yang berbeda, (5) mampu menarik kesimpulan sendiri. Selanjutnya, dieksplorasi lebih jauh penerapan model ini pada peserta didik di SMA Negeri 2 Mataram. 


\section{METODE PENELITIAN}

Teknik yang digunakan pada penelitian ini adalah jenis eksperimen semu (quasiexperimental) dengan one group pretestposttest design (Fraenkel et al., 2012). Pada penelitian ini hanya ada satu kelompok sampel yang diberikan perlakuan (treatment) pembelajaran dengan model student oriented. Sampel ditentukan dengan cara sampel bertujuan (purposive sampling), yaitu 17 peserta didik kelas XI MIPA8 dengan matapelajaran fisika pada pokok materi fluida dinamis. Data kemampuan berpikir kritis dikumpulkan menggunakan instrumen tes berbentuk soal essay sebanyak 10 item soal yang disusun mengacu pada indikator berpikir kritis, yaitu pada indikator merumuskan masalah, melakukan proses dan analisis, melakukan pengamatan,dan menemukan kesimpulan dan. Tiap satu indikator berpikir kritis terdiri dari 3 item soal. Sebelum diterapkan (implementasikan), instrumen tes diuji validitas dan reliabilitasnya. Penilaian validitas instrumen menggunakan lembar validasi berdasarkan skala Likert terdiri dari lima skala penilaian untuk setiap pernyataan item, dari sangat valid hingga tidak valid (Bahtiar \& Prayogi, 2012). Reliabilitas dihitung dengan persamaan percentage of agreement oleh Emmer dan Millet (dalam Borich, 1994). Hasil uji validitas dan reliabilitas oleh para ahli menunjukkan bahwa instrumen tes valid dan reliabel untuk selanjutnya dapat diimplementasikan. Data kemampuan berpikir kritis dianalisis secara deskriptif menggunakan skala lima diadaptasi dari teknik penskoran Ennis-Weir Critical Thinking Essay Test, di mana skor terendah -1 dan tertinggi +3 , sehingga dari 10 item soal tersebut skor terendah sebesar -10 (minus sepuluh) dan tertinggi +30 (plus dua tiga puluh). Skor dikonversi ke dalam kriteria kemampuan berpikir kritis dari tidak kritis sampai dengan sangat kritis (Prayogi, Yuanita, \& Wasis, 2018), seperti disajikan pada Tabel 1. N-gain (normality gain) yang menunjukkan peningkatan skor kemampuan berpikir kritis juga dianalisis (Hake, 1999).

Tabel 3 : Kategori kemampuan berpikir kritis

\begin{tabular}{ccc}
\hline Rentang Skor & Perhitungan & Kategori \\
\hline $\mathrm{X}>\mathrm{X}_{\mathrm{i}}+1,8 \mathrm{Sbi}$ & $\mathrm{X}>22,01$ & Sangat kritis \\
\hline $\mathrm{X}_{\mathrm{i}}+0,6 \mathrm{Sbi}<\mathrm{X} \leq$ & $14,00<\mathrm{X} \leq 22,01$ & Kritis \\
$\mathrm{X}_{\mathrm{i}}+1,8 \mathrm{Sbi}$ & & \\
\hline $\mathrm{X}_{\mathrm{i}}-0,6 \mathrm{Sbi}<\mathrm{X} \leq$ & $6,00<\mathrm{X} \leq 14,00$ & Cukup kritis \\
$\mathrm{X}_{\mathrm{i}}+0,6 \mathrm{Sbi}$ & & \\
\hline$-1,8 \mathrm{Sbi}<\mathrm{X} \leq \mathrm{X}_{\mathrm{i}}-0,6 \mathrm{Sbi}$ & $-2,01<\mathrm{X} \leq 6,00$ & Kurang kritis \\
\hline $\mathrm{X} \leq \mathrm{X}_{\mathrm{i}}-1,8 \mathrm{Sbi}$ & $\mathrm{X} \leq-2.01$ & Tidak kritis \\
\hline
\end{tabular}

Keterangan : $\mathrm{X}=$ emperical score, $\mathrm{X}_{\mathrm{i}}=$ mean ideal $=1 / 2(\max$ score $+\min$ score $)$, Sbi $=$ deviation ideal $=1 / 6$ ( $\max$ score $-\min$ score), sedangkan max score $=+30$, dan min score $=$ -10. Menurut Hake, R. (1999), nilai Gain dihitung dengan persamaan:

$$
<g>=\frac{S_{\text {post- }} S_{\text {pre }}}{S_{\text {maks- }} S_{\text {pre }}}
$$

Dimana, $\left\langle g>\right.$ adalah skor N-Gain, $S_{\text {post }}$ adalah skor tes akhir $S_{\text {pre }}$ adalah skor tes awal dan $S_{\text {maks }}$ adalah akor maksimal.

Tabel 4 : Kriteria Skor N-Gain

\begin{tabular}{cc}
\hline $\begin{array}{c}\text { Klasifikasi Skor } \\
\text { N-Gain }\end{array}$ & Kategori \\
\hline $0,7<\langle g\rangle \leq 1$ & Tinggi \\
\hline $0,3<\langle g\rangle$ & Sedang \\
$\leq 0,7$ & \\
\hline$\langle g\rangle \leq 0,3$ & Rendah \\
\hline
\end{tabular}

Berikut, adalah diagram alir penelitian ini :

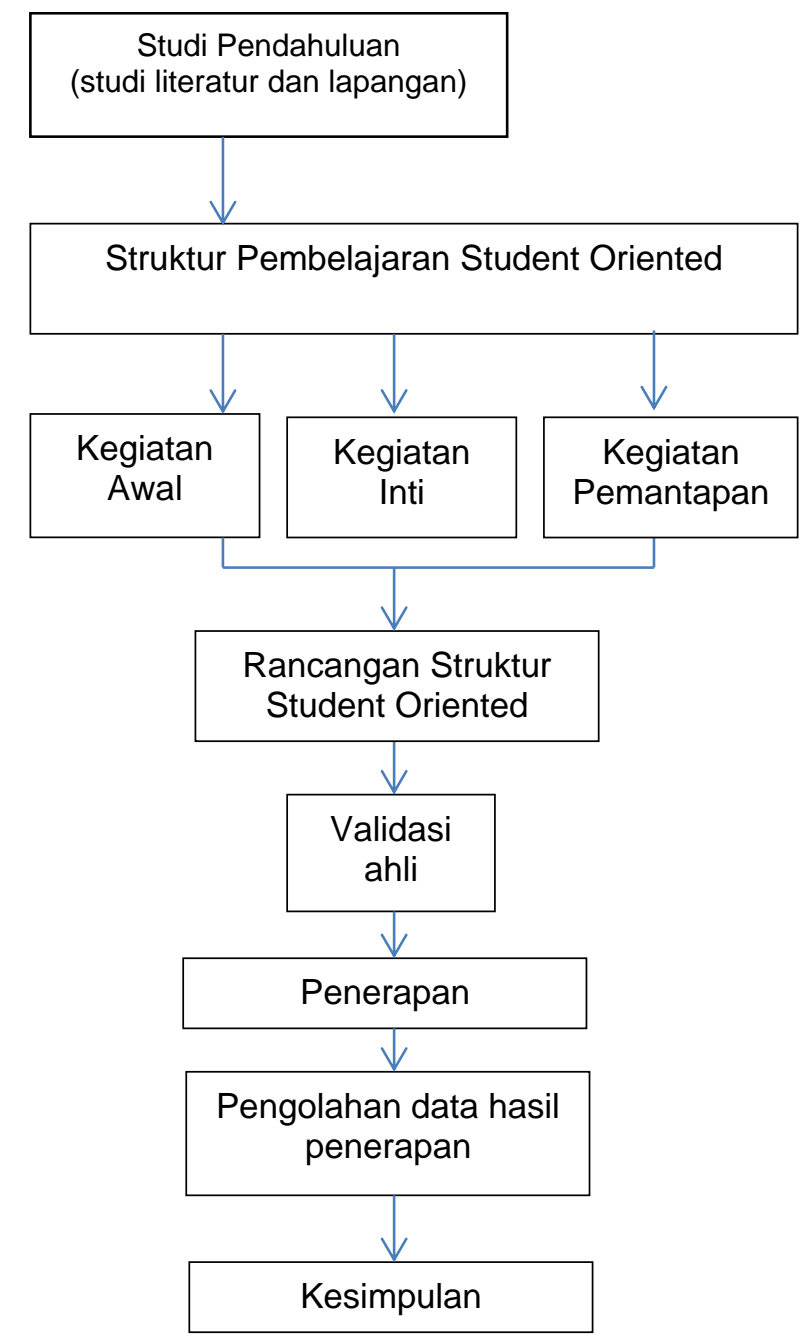

Gambar 1: Diagram Alir Penelitian

HASIL DAN PEMBAHASAN

Data penelitian hasil tes kemampuan berpikir kritis terhadap 17 peserta didik kelas XI MIPA8 
SMA Negeri 2 Mataram. berdasarkan kategori kemampuan berpikir kritis di sajikan pada tabel 5.

Tabel 5 : Kemampuan Berpikir Kritis Peserta Didik

\begin{tabular}{|l|r|r|r|r|r|}
\hline \multicolumn{1}{|c|}{ Rekap Pretest } & \multicolumn{1}{c|}{$\%$} & Rekap Posttest & \multicolumn{1}{c|}{$\%$} \\
\hline sangat kritis & 1 & 5,88 sangat kritis & 10 & 58,82 \\
\hline kritis & 3 & 17,65 kritis & 7 & 41,18 \\
\hline cukup kritis & 2 & 11,76 cukup kritis & 0 & 0,00 \\
\hline kurang kritis & 11 & 64,71 kurang kritis & 0 & 0,00 \\
\hline tidak kritis & 0 & 0,00 tidak kritis & 0 & 0,00 \\
\hline & 17 & 100,00 & 17 & 100,00 \\
\hline
\end{tabular}

dalam bentuk grafik tabel 4 disajikan sebagai berikut:

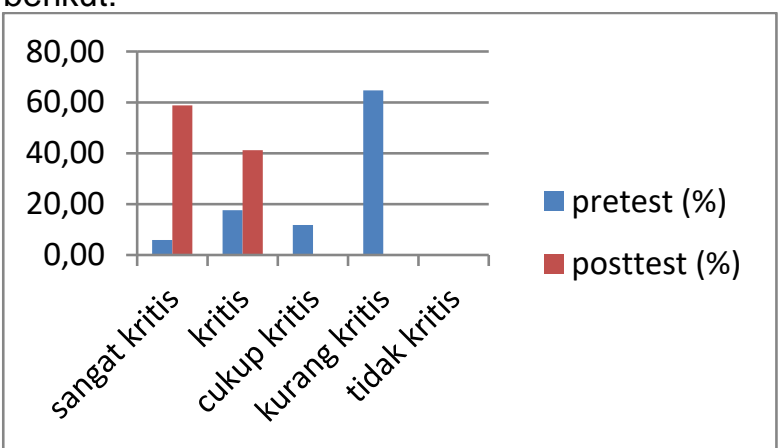

Gambar 2 : Grafik Kemampuan Berpikir Kritis Peserta Didik

Rata-rata dan N-Gain masing-masing peserta didik disajikan pada tabel 6 .

Tabel 6 : Rata-Rata dan N-Gain Peserta Didik

\begin{tabular}{|c|c|c|c|}
\hline pretest & posttest & $\mathrm{N}-$ Gain & kriteria \\
\hline 3 & 18 & 0,65 & sedang \\
\hline 3 & 18 & 0,65 & sedang \\
\hline 3 & 26 & 1,00 & tinggi \\
\hline 5 & 25 & 0,95 & tinggi \\
\hline 2 & 24 & 0,92 & tinggi \\
\hline 5 & 22 & 0,81 & tinggi \\
\hline 7 & 23 & 0,84 & tinggi \\
\hline 4 & 22 & 0,82 & tinggi \\
\hline 14 & 24 & 0,83 & tinggi \\
\hline 15 & 22 & 0,64 & sedang \\
\hline 23 & 24 & 0,33 & sedang \\
\hline 16 & 23 & 0,70 & sedang \\
\hline 10 & 23 & 0,81 & tinggi \\
\hline 4 & 18 & 0,64 & sedang \\
\hline-1 & 24 & 0,93 & tinggi \\
\hline 3 & 23 & 0,87 & tinggi \\
\hline 6 & 19 & 0,65 & sedang \\
\hline rata-rata & $\mathbf{0 , 7 7}$ & tinggi \\
\hline
\end{tabular}

Dalam bentuk grafik, tabel 6 disajikan pada gambar 2. Tabel 6 memperlihatkan N-Gain yang diperoleh masing-masing peserta didik pada kegiatan pretest dan posttest yang dilakukan dalam penelitian ini. Rata-rata NGain 0,77 dengan kriteria tinggi.

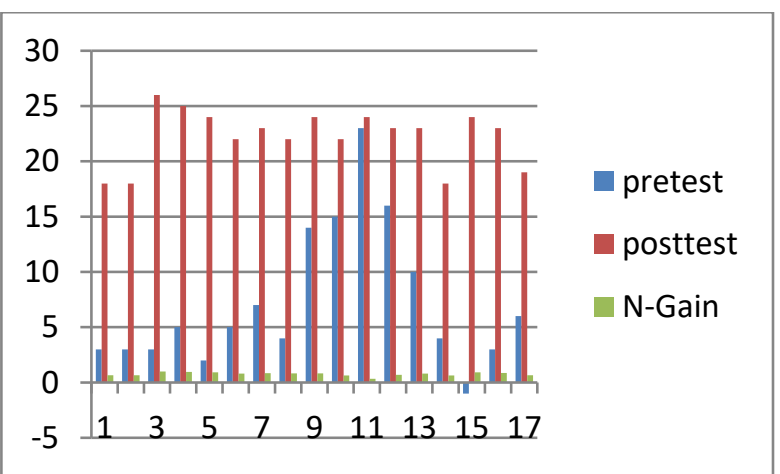

Gambar 3 : Rata-Rata dan N-Gain Peserta Didik

Secara umum, temuan ini sejalan dengan studi sebelumnya bahwa pengintegrasian aspek kreativitas ilmiah dalam proses inkuiri dapat melatih kemampuan berpikir kritis mahasiswa (Wahyudi et al., 2019). Hasil penelitian ini juga sejalan dengan temuan bahwa intervensi kreativitas ilmiah dalam pembelajaran efektif mengembangkan kemampuan berpikir kritis pebelajar (Koray, \& Köksal, 2009). Wechsler et al (2018) menyatakan bahwa pemikiran kritis dapat tercipta ketika peserta didik menggunakan kreativitas ilmiahnya dalam pembelajaran. Peningkatan kemampuan berpikir kritis peserta didik melalui model pembelajaran student oriented tidak dapat dipisahkan dari intervensi setiap fase yang dilaksanakan selama proses pembelajaran di mana fase pembelajaran secara konsisten melatih kemampuan berpikir peserta didik. Penemuan masalah dan pemecahan masalah secara kreatif merupakan dimensi kreativitas ilmiah, di mana keduanya memiliki korelasi dalam konteks melatih pemikiran kritis. Ketika pebelajar berpikir dalam konteks spesifik (berpikir kritis), mereka menggunakan berbagai proses berpikir (berpikir kreatif) (Kousoulas \& Mega, 2008). Temuan dari penelitian ini menjawab juga telah menjawab masalah utama yang dihadapi dalam pembelajaran sains, di mana mengajar sains bukan hanya pada aspek transfer pengetahuan, tetapi proses pembelajaran yang memungkinkan terjadinya kreatifitas ilmiah agar pebelajar dapat berpikir kritis (Šorgo, 2012). Yuli (2020), Ada pengaruh model learning cycle $5 E$ terhadap kemampuan berpikir kritis fisika peserta didik di sekolah menengah.

\section{SIMPULAN DAN SARAN}

Penerapan model pembelajaran student oriented pada pemecahan masalah fluida dinamis pada peserta didik mampu meningkatkan kemampuan berpikir kritis dan hasil belajar peserta didik kelas XI MIPA 8 di SMA Negeri 2 Mataram. 


\section{SARAN}

Perlu dilakukan penelitian lebih lanjut tentang analisis peningkatan kemampuan berpikir kritis peserta didik untuk tiap indikator. Selanjutnya dilakukan evaluasi serta refleksi terhadap keinginan, kemauan dan kecenderungan para pelaku kebijakan untuk melaksanakan serta mewujudkan hasil penelitian secara sungguhsungguh.

\section{UCAPAN TERIMA KASIH}

Terima kasih kami sampaikan kepada SMA Negeri 2 Mataram yang telah memberikan kesempatan, fasilitas dan dukungan dalam melaksanakan penelitian ini.

\section{DAFTAR RUJUKAN}

Abrami, P.C., Bernard, R.M., Borokhovski, E., Wade, A., Surkes, M.A., Tamim, R., \& Zhang, D. (2018). Instructional interventions affecting critical thinking skills and dispositions: A stage 1 metaanalysis. Review of Educational Research, Vol.78, No.4,1102-1134.

Aktamis, H. \& Ergin, O. (2008). The Effect of scientific proccess skill education on student's scientific creativity, science attitudes, and academic achivements. Asia-Pacific Forum on Science Learning and Teaching, Vol.9 No.1, 121.

Bahtiar, \& Prayogi, S. (2012). Evaluasi hasil pembelajaran sains (IPA). Mataram: CV. Dimensi Raya.

Bensley, D.A., \& Murtagh, M.P. (2018). Guidelines for a scientific approach to critical thinking assessment. Teaching Psychology, Vol. 39 No. 2, 5-16.

Borich, G. D. (1994). Observation skills for effective teaching. Columbus, $\mathrm{OH}$ : Merrill

Ennis, R.H. (1989). Critical thinking and subject specificity: Clarification and needed research. Educational Researcher, Vol. 18, No.3, 4-10.

Fahim, M. \& Masouleh, N.S. (2018). Critical thinking in higher education: a pedagogical look. Theory and Practice in Language Studies, Vol. 2, No. 7,1370-1375.

Fraenkel, J.R., Wallen, N.E., \& Hyun, H.H. (2012). How To Design And Evaluate Research In Education (8th ed.). New York: McGraw-Hill

Glassner, A., \& Schwartz, B. (2018). What stands and develops between creative and criatical thinking? Argumentation. Thinking Skills and Creativity, Vol. 2, No. 1,10-18.
Hake, R.R., (2008). Analyzing change/gain scores. Retrieved from $<\mathrm{http} / / /$ lists.asu.edu/cgibin/wa?A2=ind $9903 \& L=$ aera $\mathrm{d} \& \mathrm{P}=\mathrm{R} 6855>$

Halpern, D.F. (1998). Teaching critical thinking for transfer across domains. American Psychologist, Vo. 53, No. 4, h.449-455.

Koray, Ö. \& Köksal, M.S. (2018). The effect of creative and critical thinking based laboratory applications on creative and logical thinking abilities of prospective teachers. Asia-Pacific Forum on Science Learning and Teaching, Vol. 10, No. 1,1-13.

Klinger. Walter. (1997). Survei Metode Pengajaran dalam IImu Pengetahuan Alam. Erziehungswiss, Fakultat der Universtat, Erlangen-Nurnbe.

Kousoulas, F., \& Mega, G. (2008). Creative and critical thinking in the context of problem finding and problem solving: $A$ research among students in primary school. Retrieved from http://www.ep.liu.se/ecp/021/vol1/011/ ecp2107011.pdf

McPeck, J. Teaching critical thinking: Dialogue \& dialectic. New York: Routledge. Mitrevski, B. \& Zajkov, O. (2011). Mathematics and science teachers' concept of critical thinking. Bulgaria Journal of Physics, Vol.38, 318-324.

Prayogi, S. Yuanita, L., \& Wasis. (2018). Critical Inquiry Based Learning: Model of learning to promote critical thinking ability of pre-service teachers. J. Phys.: Conf. Ser. 947,1-6.

Prayogi, S., Yuanita, L. \& Wasis. (2018). Critical-Inquiry-Based-Learning: A model of learning to promote critical thinking among prospective teachers of physic. Journal of Turkish Science Education, 15(1),43-56.doi: 10.12973/tused.10220a

Sendag S., Erol O., Sezgin S., \& Dulkadir N. (2015). Preservice teachers' critical thinking dispositions and web 2.0 competencies. Contemporary Educational Technology, Vol. 6, No.3, 172-187.

Šorgo, A. (2012). Scientific Creativity: The Missing Ingredient in Slovenian Science Education. European Journal of Educational Research, Vol. 1, No. 2,127-141.

Schmaltz, R. M., Jansen. E, \& Wenckowski, N. (2017). Redefining critical thinking: Teaching students to think like scientists. Front. in Psych, Vol. 8 N0. 459, 1-4. 
Thomas T. (2017). Developing first year students' critical thinking skills. Asian Social Science, Vol. 7, No. 4, 26-35.

Türkmen, H. \& Sertkahya, M. (2015). Creative thinking skills analysis of vocational high school students. Journal of Educational and Instructional Studies in the World, Vol. 5, No. 1, 74-84.

Wahyudi, Verawati, N.N.S.P., Ayub, S., \& Prayogi. (2019). Development of inquiry-creative-process learning model to promote critical thinking ability of physics prospective teachers. Journal of Physics: Conf. Series 1108, 1-6. doi: 10.1088/1742-6596/1108/1/012005

Wechsler, S.M., Saiz, C., Rivas, S.F., Vendramini C.M.M., Almeida L.S., Mundim M.C., \& Franco A. (2018). Creative and critical thinking: Independent or overlapping components? Thinking Skills and Creativity, Vol. 27,114-122.

Yuli, H., (2020). Kemampuan berpikir kritis momentum dan impuls ditinjau dari gaya belajar peserta didik dengan model Learnig cycle 5E, Jurnal orbita Ummat. Vol. 6 No.1,188-195

Zane, T. (2013). Implementing critical thinking with signature assignments. Salt Lake Community College, Springer. 